\title{
Specific Learning Difficulties and Their Assessment Models: A Study from Inclusive Elementary Schools
}

\author{
Ibnu Syamsi \\ Department of Special Education \\ Yogyakarta State University, Indonesia \\ ibnu_syamsi@uny.ac.id
}

\author{
Haryanto \\ Department of Special Education \\ Yogyakarta State University, Indonesia \\ haryanto@uny.ac.id
}

\begin{abstract}
This study aims to identify specific learning difficulties and assessment models appropriate for inclusive elementary school (ES) students in Sleman Regency, Yogyakarta, Indonesia. Data were collected through observation, tests, interviews, and surveys, and analyzed by qualitative and quantitative descriptive statistics. The results show that $85(18.27 \%)$ of 465 participants have certain learning difficulties, namely dysgraphia (22.10\%), dyslexia (19.55\%), and dyscalculia (30.60\%). It suggests that for assessing the difficulties, assessment guidelines for formal and informal assessment should be appropriately developed by considering their learning needs.
\end{abstract}

Keywords: learning difficulties, assessment, inclusive, elementary school

\section{INTRODUCTION}

The specific learning difficulty is often called as one problem in education. It involves the students' inability to complete their academic tasks appropriately. Larsen (2002) claims specific learning difficulties as the conditions experienced by students related to barriers, delays, and lags in the ability to read, write, and calculate. Kauffman (2008) reveals that the prevalence of specific learning difficulties varies greatly, from $1 \%$ to $30 \%$. In general, it has increased from year to year. However, if such difficulties are appropriately addressed and even the other related issues are covered in some media, the society and some interested parties can devote greater attention to various disabilities of special need students and the issues emerging in their family (Almakanin \& Alodat, 2018).

Cases of specific learning difficulties, as the portrait of education in Sleman Regency, Yogyakarta, Indonesia especially in elementary education, were shown by the high number of state and private ES students who repeat the class. The implications of this phenomenon become very interesting because it was contrary to the education equalization policy. In other words, the students repeating could ruin the quota of the new students or students going to the higher grade. This certainly affects the level of education efficiency (Education Department of Sleman, 2014). It could be concluded that the problems of specific learning difficulties have an impact on the students' academic achievements, in particular, and generally affect the low efficiency and effectiveness of education.

Based on the background of the problem, the research objectives were to identify: (1) types of specific learning difficulties in reading, writing, and math/numeracy difficulties; and (2) assessment models that could be used to deal with students in the classroom. The scope of this study is learning difficulties that were not caused by physical limitations (abnormalities or developmental barriers), which were experienced by students in regular education in inclusive elementary schools. Academic assessment, discussed in this paper, is mainly focused on the three things, i.e. reading, writing, and math/numeracy assessment.

In general, the purpose of identification is to gather information about whether a child has specific learning difficulties. Children may experience specific learning difficulties, of course, when compared to other regular children of the same age. Ghozali (2003) states that the results of identification would be assessed, and some of which would be used as the basis for the preparation of learning programs in accordance with the abilities and inabilities of children with specific learning difficulties. Identification could be interpreted as recognizing or a screening process while the assessment was defined as filtering. Manning (2001) argues that in the effort to implement assessment, the identification of children with specific learning difficulties was carried out for five objectives, namely (1) screening, (2) referral, (3) classification, (4) planning, and (5) monitoring. Besides, there have been several steps proposed to identify children with specific learning difficulties. Yusuf \& Legowo (2007) state that with regard to the identification of school-age children who have not yet attended a school or dropped out, the schools need to collect data from the community, collaborating with the head of villages, neighborhood units, community units, and head of integrated health service post. Similarly, Patto (2003) argues for students at schools the identification can be done by collecting data on children; at this stage, the teachers record data on the student condition in the class (based on the visible symptoms).

With regard to assessment, Marnat (2003) defines assessment as the collection of information that helps individuals make decisions and additionally proposes that in the assessment process there are four aspects of important questions that must be revealed related to the condition of an individual. The inquiries are (a) what abilities or skills he/she already has, (b) what obstacles or difficulties he/she experienced, (c) why the obstacles or difficulties happen, and (d) what needs (in terms of 
education and learning) should be met. Loughlin (2003) adds that assessment for children with specific learning difficulties is a systematic process using relevant instruments to determine children's learning behaviors for the purpose of placement and learning.

\section{METHOD}

As learning difficulties may hinder the learning process, this study attempts to identify types of difficulties faced by students in inclusive elementary schools, especially in terms of reading, writing, and math/numeracy and later suggests the possible assessment models appropriate for the three mentioned learning difficulties so that each learner can be provided with the necessary supporting treatments and facilities to maximize their learning.

The research subjects were students from 25 inclusive, either public or private ESs in Sleman Regency, Yogyakarta Special Province, Indonesia. The population was all grade one to six students from inclusive ESs in the researched regency. As many as 465 sample students were determined by using stratified random sampling. They consisted of a portion of third-to-sixth grade students having obstacles in learning and those having low learning outcomes.

The data were collected by an observation guideline, interview guideline, and both formal and informal tests. The study was carried out by planning, the development of the observation and interview guideline, and tests, data collection (observing, interviewing, and testing the students), and data analysis.

This study employed qualitative descriptive data analysis by organizing data into categories, describing into units, synthesizing, arranging into patterns, choosing which ones are important and which ones must be learned, and make conclusions so that they are easily understood by themselves and others (Sugiyono, 2003). Data analysis was carried out before, whilst, and after the research was completed in the field as reinforced by Miles and Huberman (Sugiyono, 2003).

\section{RESULTS}

The results of the current study show that out of 465 third and fourth grade students from five inclusive elementary schools (ESs) in Gamping Subdistrict, Sleman Regency (i.e., Inclusive Elementary Schools Turusan II, Tegalyoso I, Gamping I, Muhammadiyah Dukuh, and Patran) as many as 85 students experience learning difficulties specifically in the category of dyslexia, dysgraphia, and/or dyscalculia. In other words, of all third- and fourth-grade students, $29.65 \%$ had special learning difficulties. The percentage of students identified as having special learning difficulties varied for each school. More male students experience specific learning difficulties than do female students $(55.3 \%$; 44.7\%). The specific types of learning difficulties are 26 students $(22.10 \%)$ suffer from dyslexia, 23 children (19.55\%) suffer from dysgraphia, and 36 children $(30.60 \%)$ suffer from dyscalculia.

The study shows that the reading difficulties (dyslexia) identified are stuttering, omitting words or syllables, reversing order of words or syllables, adding extra words or syllable, doing self-correction, showing hesitation, reading in unusual ways, reversing order of letters, omitting letters, inserting words, adding extra letters, pointing each word to be read, reading with no expression, jumping over words, sentences, or lines, paying no attention to punctuation, chopping off syllables incorrectly, spelling incorrectly, producing a strange tone indicating tense, pronouncing words incorrectly, pronouncing words with teacher's help, repeating, and moving head when reading. Meanwhile, writing difficulties (dysgraphia) identified in this study include illegible writing (no space between sentences and word/letter, letter formation, slant of handwriting, pencil pressure on paper, and how to hold a pencil), problems of spelling (missing letters, reflecting dialect, incorrect letter order in words, reversed order of double vowels, syllable reversals, extra letters), errors in chopping off syllables, and capitalization errors. Lastly, the mathematical or numerical difficulties (dyscalculia) identified involve incomprehensibility of symbols $[(+),(-),(x)$ and (:)], place values, calculations, erroneous processes, and illegible writing.

\section{DISCUSSION}

With regard to specific learning difficulties, in Individuals with Disabilities Education Act (IDEA, 2007), it was stated that "specific learning disability" means a disorder in one or more basic psychological processes involved in understanding or using spoken or written language, which was manifested in imperfect abilities to hear, speak, read, write, spell, or to do mathematical calculations (Lerner, 2007). This definition could not be applied to children who have learning problems especially those caused by visual, motor, and hearing impairments; mental retardation; emotional disorder; and adverse environmental, cultural or economic conditions (Graziano, 2004).

Broadly speaking, Kauffman (2008) classifies specific learning difficulties into two groups: developmental and academic learning difficulties. The first issue to discuss, academic learning difficulties in reading (dyslexia), vary but all were possibly caused by the brain malfunction. Kauffman (2008) further states there were four characteristic groups of difficulties in reading: reading habits, mistakes in recognizing words, misunderstanding, and miscellaneous symptoms. The assessment of the learning difficulties to read could be done using formal and informal instruments. Teachers could use informal instruments as a basis for providing remedial teaching. The informal assessment could be used to identify various errors in oral reading and reading comprehension.

Based on the observation and test results in reading, the students who experience specific learning difficulties make various errors such as omitting, inserting, replacing, reversing, mispronouncing, reversing the order, inability to recognize words, and stuttering. Another apparent error is the misreading of words because of low visual discrimination. The students with specific learning will specifically read the word "mengelabui" with "mengebui". The incompetence happens not only in visual but also auditory discrimination. When dictated, students with specific learning difficulties will make mistakes in words, for 
example, some words will be inaccurately written (menggergaji - meggeraji; kanvas - kampas; mengejar megejar). Project IDEAL (2013), reading comprehension is the ability to understand written material. If a student with learning disabilities has difficulty in reading written materials, comprehension will always be greatly affected. While problems with word analysis can affect reading comprehension, other factors that may contribute to problems with reading comprehension include the inability to successfully identify and organize information from the material. Some of the most common reading disabilities are word analysis, fluency, and reading comprehension (Project IDEAL, 2013). According to Mathew (2003), the causes of errors in reading are: (1) deficiencies in visual and auditory memory, non-optimum short- and long-term memory; (2) problems in remembering data; and (3) poor spelling.

As found, the types of mispronunciation experienced by the research subjects are: (1) incorrect pronunciation with different meanings; (2) incorrect pronunciation with the same meaning; and (3) incorrect pronunciation with meaningless words. This kind of situation occurs because the students do not recognize letters so that they make a guess. Maybe it is because they read too fast, feel depressed or are afraid of the teacher, or because of differences in children's dialects with standardized Indonesian. For example, "tukang mereparasi mesin" is read "tukang mereparasi misin". In pronouncing words, the students identified as having dyslexia are assisted by the teacher because the teacher has been waiting for a while, but the students have not yet recited the expected words. Hallahan et al. (2005) state that the students who need this kind of assistance are usually caused by an inability to recognize letters or because they are afraid of the risks if something goes wrong. Such students also have less self-confidence, especially when facing reading tasks.

Globally, dyslexic cases range from $5 \%$ to $17 \%$ in school-age children. About $80 \%$ of school-age children suffer from dyslexia. Uniquely, dyslexia cases were suffered by more boys than girls. The scale ranges from 2 : 1 to $5: 1$ (Solek, 2013). This disorder was not caused by the inability of vision, hearing, intelligence, or skills in language, but it was triggered by a brain disorder when processing the information, it receives. Signs in the risk group of dyslexia include difficulties to spell, distinguish letters "b" and "d", write correctly (missing or extra letters in writing), remember the left and right direction, identify time (today, yesterday, tomorrow), remember sequence, follow verbal instructions, concentrate, have long attention span, communicate both orally and in writing (the language was stiff and not sequential), count especially in word problems, and read. Another sign may also be indicated by low self-confidence.

Assessment of the learning difficulties in reading can be done using formal and informal instruments. Teachers can use informal instruments as a basis for providing remedial teaching. Informal assessment can be used to identify various errors in oral reading and reading comprehension. Before conducting an assessment, a teacher must first understand the scope of reading skills as an assessment object. Hays (2007) argues that there are five aspects of reading skills: phonemic awareness, alphabet principles, accuracy and fluency, mastery of vocabulary, and reading comprehension. The five aspects of reading skills run sequentially, meaning that a certain skill was prerequisite for the next skill. While according to Graziano, (2004), there are five aspects of reading skills: phonemic awareness, alphabet principles, accuracy and fluency, mastery of vocabulary, and reading comprehension. In this paper, examples of the academic assessment are explained in every aspect of reading skill. Studying the examples, the teachers are expected to develop their own guides according to their respective needs including assessments of: (1) phonemic awareness; (2) alphabet awareness principles; (3) accuracy and fluency; and (4) reading comprehension (Graziano, A.M. 2004). Concerning this, there are two models in teaching reading, namely teaching for regular children and for children with specific learning difficulties. The teaching model for regular children includes methods such as basic reading, phonetic, linguistic, SAS, alphabetical, and language experience.

Regarding the second type of difficulty, Markam (2009) says that there are various factors influencing the ability to practice handwriting, namely motor control, behavior, perception, and memory. Assessment of learning difficulties in writing (dysgraphia) can be done using formal and informal assessment instruments and Markam (2009) states that dysgraphia is assessed through handwriting practices (beginner writing), spelling, and expressive writing.

In the third found issue are learning difficulties in mathematics (dyscalculia). The students' difficulties in mathematics, according to Lerner (2007), are caused by several things, namely interference in spatial relations, visual perception, and motor visual associations; perseveration; difficulties in recognizing and understanding symbols, and in language and reading; and impairment of body image. Project IDEAL (2013) suggests that specific problems may include difficulty understanding size and spatial relationships and concepts related to direction, place value, decimals, fractions, and time and difficulty remembering math facts. Remembering and correctly applying the steps in mathematical problems (such as the steps involved in long division) and reading and solving word problems are significant problem areas.

With regard to dyscalculia, Graziano (2004) argues that there are several principles of teaching models and remedial mathematics which can be used as assessment models as well. They include (1) children should be prepared to learn mathematics; (2) learning starts from the concrete to the abstract; (3) enough opportunities to practice and repeat should be provided; (4) generalization is done to new situations; (5) it is based on the students' strengths and weaknesses; (6) strong foundation of mathematical concepts and skills should be built; (7) balanced math programs are provided; and (8) the use of calculators is promoted to support mathematical reasoning.

\section{CONCLUSIONS}

This study has successfully revealed three types of learning difficulties that students in the researched area are suffered from, they are dyslexia, dysgraphia, and 
dyscalculia, and that such difficulties are more prevalent on male students. Difficulties in reading (dyslexia) vary but all are likely caused by brain disorders. There are four characteristic groups of reading difficulties, reading habits, mistakes in recognizing words, misunderstandings, and other symptoms. In each aspect of reading and learning skills from the examples, teachers are expected to develop their own assessment guidelines according to their students' individual needs. Besides, difficulties in writing (dysgraphia) are demonstrated through the practice of handwriting, writing beginners, spelling, and expressive writing, and they can be assessed by using formal and informal assessment instruments. Lastly, common mistakes made by children with special needs in mathematics include understanding symbols, place values, and calculations. Assessing learning difficulties specifically in math/numeracy requires that children must be prepared to learn mathematics; learning from the concrete to the abstract; more opportunities to practice and repeat must be provided; generalizations made for new situations; based on student strengths and weaknesses; a strong foundation of mathematical concepts and skills must be built; balanced math programs are provided; and the use of calculators is permitted to support mathematical reasoning. Later, by appropriate assessment and support to specific learning difficulties, it is expected that such community-based support can be promoted (Nowak, 2018) by schools in order that specialized students can integrate, learn, and live normally as other common students.

\section{REFERENCES}

[1] Act of the Republic of Indonesia No. 4 Year 2007 on People with Disabilities. Jakarta: Media Elektronika Sekretariat Negara.

[2] Ahmadi, A., \& Supriyono, W. (2004). Psikologi Belajar (Psychology of Learning). Jakarta: PT Rineka Cipta.

[3] Almakanin, H. A., \& Alodat, A. M. (2018). Issues of Children with Disabilities as Reflected in the Jordanian Media from their Parents' Perception: A SWOT Analysis. The New Educational Review, 52(21), 271-293.

[4] Education and Culture Department of the Republic of Indonesia. (2004). Pedoman Pendataan Anak Berkelainan (Guidelines for Collecting Data on Disabled Children). Jakarta: Education and Culture Department of the Republic of Indonesia.

[5] Ferguson, D. L. (2008) International Trends in Inclusive Education: The Continuing Challenge to Teach Each One and Everyone. European Journal of Special Needs Education, 23(2), 109-120.

[6] Fletcher, J. M. (2002). Assessment of Reading and Learning Disabilities A Research-Based InterventionOriented Approach. Journal of School Psychology, 40(12), 27-63.

[7] Ghozali, E. W. (2003). Deteksi Dini Aspek Sosial Psikologis Anak Balita (Early Detection of Psychological Social Aspects of Toddlers). Surabaya: East Java Health Department.
[8] Graziano, A. M. (2004). Developmental Disabilities: Introduction to A Diverse Field. Boston: Allyn and Bacon.

[9] Hallahan, D. P., \& Kauffman, J. M. (2008). Exceptional Children: Introduction to Special Education. New Jersey: Prentice Hall.

[10] Hays, P. A. (2007). Addressing Cultural Complexities in Practice: Assessments, Diagnosis, and Therapy. Washington DC: American Psychology Association.

[11] Indonesian Special School Development Directorate. 2007. Pedoman Pendataan Anak Berkelainan (Guidelines for Collecting Data on Disabled Children). Jakarta: Education and Culture Department of the Republic of Indonesia.

[12] Kauffman, J. M. (2008). Exceptional Children: Introduction to Special Education. New Jersey: Prentice Hall

[13] Larsen, S. C. (2002). Assessment in Special and Remedial Education. Boston: Houghton Mufflin Co.

[14] Lerner, J. (2007). Learning Disabilities: Theories, Diagnosis, and Teaching Strategies. Boston: Houghton Mifflin Company.

[15] Loughlin, M. (2003). Assessing Special Student Columbus. Charles E. Merrill. Chapter 11, pp 292-339 on classroom Behavior.

[16] Manning, L. (2001). Major's Physical Diagnosis: An Introduction to the Clinical Process. Philadelphia: Saunders Co.

[17] Markam, S. (2009). Pengenalan Kesulitan Belajar dan Disfungsi Minimal Otak (DMO) (Introduction to Learning Difficulties and Minimal Brain Dysfunction). Jakarta: FK UI.

[18] Marnat, G. (2003). Handbook of Psychological Assessment. Hoboken, NJ: Wiley.

[19] Mathew, T. S. (2003). A Review of the Learning Disability Evaluation Scale (LDES). Journal of School Psychology, 39(3), 279-284.

[20] Nowak, A. 2018. Support for Adults with Disabilities. The New Educational Review, 51(21), 258-266.

[21] Patto, J. R. (2003). Speech Handicapped School Children. New York: Harper and Brothers Pub.

[22] Project IDEAL. (2013). Specific Learning Disabilities, Texas Council for Developmental Disabilities. Retrieved 2 July 2019, from http://www.projectidealonline.org/v/specific-learningdisabilities/.

[23] Solek, P. (2013). Dyslexia Today Genius Tomorrow. Bandung: Dyslexia Association of Indonesia Production.

[24] Sugiyono. (2003). Metode Penelitian Bisnis. Bandung: Alfabeta.

[25] UNESCO. (2004). The Salamanca Statement and Framework for Action on Special Needs Education. Paris: UNESCO.

[26] Universal Declaration of Human Right (Deklarasi Universal Hak Asasi Manusia). (2008). New York: United Nations.

[27] Yesseldyke, J. E. (2001). Assessment in Special and Remedial Education. Boston: Houghton Mufflin Co.

[28] Yusuf, M., \& Legowo, E. (2007). Mengatasi Kebiasaan Buruk Anak Dalam Belajar Melalui Pendekatan Modifikasi Perilaku (Overcoming the Bad Habits of Children in Learning Through a Behavior Modification Approach). Jakarta: Ministry of National Education, Directorate General of Higher Education. 